\title{
ŠUOLIŲ ATLIKIMO TIKSLUMO IR STABILUMO KAITA MOKYMOSI METU
}

\author{
Edita Lingytė, Albertas Skurvydas, Jūratė Kudirkaitė, Kazimieras Pukẻnas, \\ Tomas Venckūnas, Viktoras Šilinskas, Raminta Sakalauskaitė \\ Lietuvos kūno kultūros akademija, Kaunas, Lietuva
}

\begin{abstract}
Edita Lingytė. Biologijos mokslo krypties doktorantė. Lietuvos kūno kultūros akademijos Lengvosios atletikos katedros asistentė. Moksliniu tyrimų kryptis - motorinės sistemos kompleksinè ir dinaminè adaptacija.
\end{abstract}

\section{SANTRAUKA}

Tyrimo tikslas - ištirti, kaip mokomasi judesiu stabilumo ir tikslumo 9 pratybu metu atliekant vertikalius 30\% maksimalaus aukščio šuolius.

Buvo tiriami nesportuojantys fiziškai aktyvūs vyrai $(n=8)$, kuriu amžius $-20,3 \pm 0,7$ metu, ügis $-182,0 \pm 3,5 \mathrm{~cm}$, küno svoris - 77,5 $\pm 9,1 \mathrm{~kg}$. Tiriamieji 3 savaites (3 kartus per savaite) mokèsi tiksliai atlikti 30\% maksimalaus aukščio šuolius ant KISTLER tenzoplokštés. Šuoliai buvo atliekami be ranku mosto (rankos laikomos ant klubu), amortizuojamai pritūpus per keliu sqnarius iki $90^{\circ} \mathrm{kampo,} \mathrm{liemuo} \mathrm{-} \mathrm{vertikalios} \mathrm{padèties.} \mathrm{Po} \mathrm{lèkimo} \mathrm{fazés} \mathrm{nusileidžiant,}$ kelio sqnarys buvo maždaug $180^{\circ}$ kampu. Likus 4 dienoms iki tyrimo, tiriamieji supažindinti su jo eiga ir pamokyti taisyklingai atlikti vertikalius maksimalaus pajëgumo šuolius. Kiekvienos mokymosi dienos pratybu pradžioje buvo atliekami 3 šuoliai maksimaliomis pastangomis, ir pagal geriausia rezultata nustatomas 30\% šuolio aukštis. Per vienerias šuoliu mokymosi pratybas buvo atliekami 100 30\% maksimalaus aukščio šuoliu. Po paskutinio pašokimo praèjus 3 min, vèl buvo atliekami 3 maksimaliu pastangu šuoliai.

Rezultatai parodè, kad tiriamuju kiekvienos dienos maksimalus šuolio aukštis, išmatuotas prieš pratybas ir po ju, išliko nepakitęs ( $p>0,05)$. Palyginus pirmu ir paskutiniu pratybu absoliučias ir kaitumo klaidas, nustatytas statistiškai patikimas skirtumas $(p<0,05)$ - devintose šnoliu mokymosi pratybose tiriamiesiems atliekant $30 \%$ maksimalaus aukščio šuolius nustatyti mažiausi kaitumo ir absoliučiu klaidu dydžiai. Per 9 pratybas labiausiai pakito kaitumo klaidos, skirtumas nио pirmu pratybu - 34,4 \pm 0,2\%. Per pirmas pratybas atliekant pirmus 10 šuoliu nustatytos didžiausios absoliučiu ir kaitumo klaidu reikšmès, lyginant su kitu seriju šuoliais ( $p<0,05)$.

Taigi galima daryti išvada, kad mokymasis kuo tiksliau atlikti 30\% maksimalaus aukščio šuolius sumažina pašokimo kaitumo ir absoliučiu klaidu dydị. Vidiniai modeliai, padedantys tiksliai atlikti judesius, susidaro jau po 10 šuoliu.

Raktažodžiai: judesiu mokymasis, vertikalūs šuoliai, vidiniai modeliai.

\section{IVADAS}

J udesių išmokimas priklauso nuo: pratybų išdèstymo (Lee, Genovese, 1989; Wulf, Shea, 2002), ju kiekio (Korman et al., 2003), instruktavimo aiškumo (Shapiro, Schmidt, 1982; Magill, Hall, 1990), dèmesio sukoncentravimo (McCullagh et al., 1989; Jeannerod, 1994), grižtamosios informacijos suteikimo trukmès, rūšies ir dažnumo (Salmoni et al., 1984; Shmidt, 1991).

Judesių mokymasis apibūdinamas kaip pastangos tiksliai ir stabiliai ịvairiomis sąlygomis atlikti judesi, pavyzdžiui, važiuoti dviračiu (Mattar,
Gribble, 2005). Motorinè sistema prisitaiko prie naujos dinaminès aplinkos sukurdama vidinius modelius, kurie tarsi numato raumenu jègą, reikalingą kuo efektyviau atlikti judesi (Takahashi et al., 2006). Šie modeliai susikuria ne iš karto (Shadmehr, Mussa-Ivaldi, 1994). Besimokant gerẻja judesių atlikimo tikslumas ir tolygumas (Shadmehr, Wise, 2005). Judesių mokymosi tyrimai daugiausia vyksta tiriamiesiems atliekant ranku judesius (Mattar, Gribble, 2005; Bays, Wolpert, 2006; Cothros et al., 2006). Neaptikome darbu, 
nagrinėjančių judesių mokymąsi atliekant nustatyto aukščio vertikalius šuolius.

Buvo iškeltos dvi hipotezès. Pirma, daroma prielaida, kad mokymasis kuo tiksliau atlikti 30\% maksimalaus aukščio šuolius sumažins pašokimo i nurodytą aukšti kaitumo (rodo judesio kaituma ir stabilumą) ir absoliučiu (rodo judesio tikslumą) klaidu dydi. Antra, manome, kad vidiniai modeliai, padedantys tiksliai atlikti judesius, susidarys atlikus $10-20$ šuoliu.

Tyrimo tikslas - ištirti, kaip mokomasi judesiu stabilumo tikslumo 9 pratybų metu atliekant vertikalius $30 \%$ maksimalaus aukščio šuolius.

\section{TYRIMO METODIKA}

Tiriamieji. Buvo tiriami jauni fiziškai aktyvūs vyrai $(\mathrm{n}=8)$, kuriu amžius $(\overline{\mathrm{x}} \pm \mathrm{SD})-20,3 \pm 0,7$ metų, ūgis - 182,0 $\pm 3,5 \mathrm{~cm}$, kūno svoris $77,5 \pm 9,1 \mathrm{~kg}$. Tiriamieji, likus 4 dienoms iki tyrimo, buvo supažindinami su būsimo eksperimento eiga ir pamokyti, kaip taisyklingai atlikti maksimalaus intensyvumo šuolius.

Šoklumo testavimas. Tiriamieji po $10 \mathrm{minu}-$ čių lèto bėgimo atliko maksimalaus intensyvumo vertikalius šuolius, amortizuojamai pritūpdami per kelių sąnarius iki $90^{\circ}$ kampo ir liemeni laikydami vertikalų. Šuolio metu rankos buvo ant klubu. Po lèkimo fazès nusileidžiant, kelio sąnarys buvo maždaug $180^{\circ} \mathrm{kampu}$. Šuoliai buvo atliekami ant KISTLER tenzoplokštès (BioWare Performance Software Version 3.0 Type 2812A2-3. Operating Instruction. Kistler Instrumente AG Winterthur). Šuolio aukštis $(h)$ apskaičiuojamas pagal formulę:

$$
h=\frac{g \times t_{p}^{2}}{8}=1,226 \times t_{p}^{2},
$$

čia: g — laisvojo kritimo pagreitis $\left(9,81 \mathrm{~m} / \mathrm{s}^{2}\right) ; \mathrm{t}_{\mathrm{p}}$ 一 šuolio lèkimo fazès trukmè (s).

Šuolio tikslumui ịvertinti buvo apskaičiuojamos absoliučios ir kaitumo klaidos (Schmidt, Lee, 1999; Magill, 2006).

1 pav. Šuolio aukščio tikslumo mokymosi protokolas
Absoliučios klaidos suteikia informacijos apie klaidos dydi, rodo judesiu tikslumą. Jos buvo apskaičiuojamos pagal formulę:

$$
\text { Absoliuti klaida }=\sum\left|x_{i}-T\right| / n,
$$

čia: $\mathrm{x}_{\mathrm{i}}$ - šuolio aukštis $(\mathrm{cm}) ; \mathrm{T}-30 \%$ maksimalaus aukščio šuolis (MAŠ) $(\mathrm{cm}) ; \mathrm{n}$ - bandymų skaičius; vertikalūs skliausteliai (||) reiškia, kad juose esanti reikšmė visada buvo laikoma teigiama.

Absoliučios klaidos rodo absoliutu nuokrypi nuo reikiamo šuolio aukščio. Pvz.: jei tiriamajam reikia stengtis atlikti $30 \%$ MAS $(12 \mathrm{~cm})$, o jis pašoka $14,5 \mathrm{~cm}$, tai absoliutus nuokrypis lygus $2,5 \mathrm{~cm}$. Arba, jei pašoka $9 \mathrm{~cm}$, tai absoliutus nuokrypis lygus $3 \mathrm{~cm}$.

Kaitumo klaidos (šuolių stabilumo) buvo apskaičiuojamos pagal formulę:

$$
\text { Kaitumo klaida }=\sqrt{\sum\left(x_{i}-M\right)^{2} / n},
$$

čia: $x_{i}$ - šuolio aukštis $(\mathrm{cm}) ; \mathrm{M}$ - šuolių aukščio vidurkis (cm); n - bandymų skaičius.

Kaitumo klaidos rodo šuoliu atlikimo kintamumą, nesuderinamumą arba, atvirkščiai, judesių atlikimo nuoseklumą (darnuma), stabilumą (Schmidt, Lee, 1999; Magill, 2006).

Tyrimo organizavimas. Likus 4 dienoms iki tyrimo, tiriamieji buvo supažindinami su tyrimo eiga ir pamokyti taisyklingai atlikti vertikalius maksimalaus pajègumo šuolius. Po 4 dienų tiriamieji 3 savaites (3 kartus per savaitę) mokèsi tiksliai atlikti $30 \%$ maksimalaus aukščio šuolius. Per vienerias pratybas buvo atliekami $10030 \%$ MAŠ. Vienerių pratybų eiga (1 pav.):

- 10 min pramankšta (lètas bègimas, kai pulso dažnis $120-130 \mathrm{tv}$. / min).

- 3 maksimalių pastangų šuoliai (intervalai tarp šuoliu $-20 \mathrm{~s}$ ), pagal geriausią tos dienos rezultatą nustatomas $30 \%$ šuolio aukštis.

- Pailsejjus 3 min atliekama 100 30\% MAŠ, gaunant žodinę grižtamają informaciją apie ką tik atlikto šuolio aukštic. Poilsis tarp šuoliu $-5 \mathrm{~s}$. Tiriamajam atlikus tikslų šuolị (30\% MAŠ),

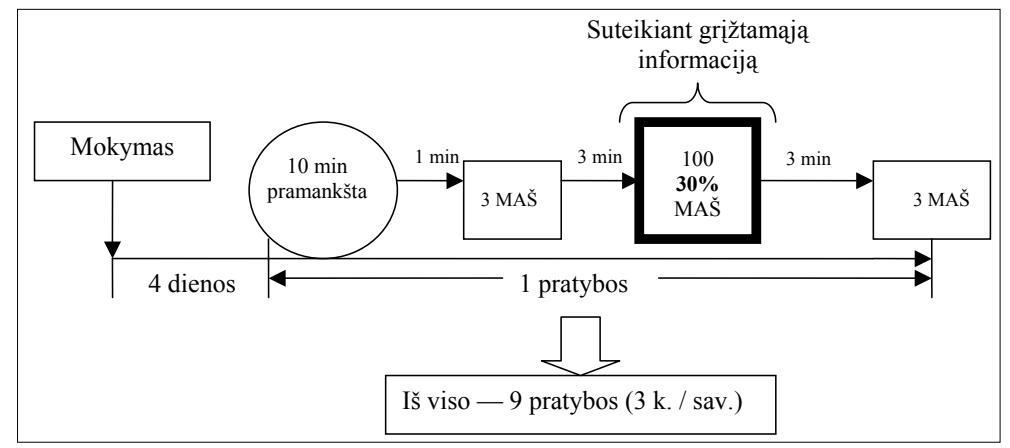


t. y. pasiekus $\pm 0,4 \mathrm{~m}$ reikiamo aukščio, jis pagiriamas (pvz., ,šaunuolis“, „labai gerai“).

- Po 3 min atliekami 3 maksimalių pastangų šuoliai (poilsis tarp šuoliu — 20 s), registruojamas geriausias rezultatas.

Matematinė statistika. Išanalizavus tyrimo duomenis, apskaičiuotas aritmetinis vidurkis $(\overline{\mathrm{x}})$, vidutinis standartinis nuokrypis (s), skirtumo tarp vidurkių statistinis patikimumas $(\mathrm{p})$, procentiné rezultatų kaita. Skirtumo tarp aritmetinių vidurkiu reikšmingumas buvo nustatomas pagal dvipusi priklausomų imčių Stjudento $t$ kriterijų. Skirtingu veiksnių rezultatų reikšmingumui ịvertinti taikyta dviejų veiksnių dispersinè analizè. Skirtumas statistiškai reikšmingas, kai $\mathrm{p}<0,05$. Naudojant SPSS programų paketa, atlikta dviejų lygių kartotinių bandymų (pagal testų dienas ir šuoliu serijas (10 serijų po 10 šuolių ir 4 serijos po 25 šuolius)) analizè.

\section{REZULTATAI}

Tyrimo rezultatai parode, kad kiekvienos dienos maksimalus šuolio aukštis, išmatuotas prieš pratybas ir po ju, nepasikeite (p >0,05) (2 pav.).

Per 9 pratybas kaitumo klaidos sumažèjo $34,4 \pm 0,2 \%$, absoliučios $-29,3 \pm 0,3 \%(p<0,01)$ (3 pav.). Kaitumo klaidos sumažejjo reikšmingai daugiau nei absoliučios $(\mathrm{p}<0,05)$.
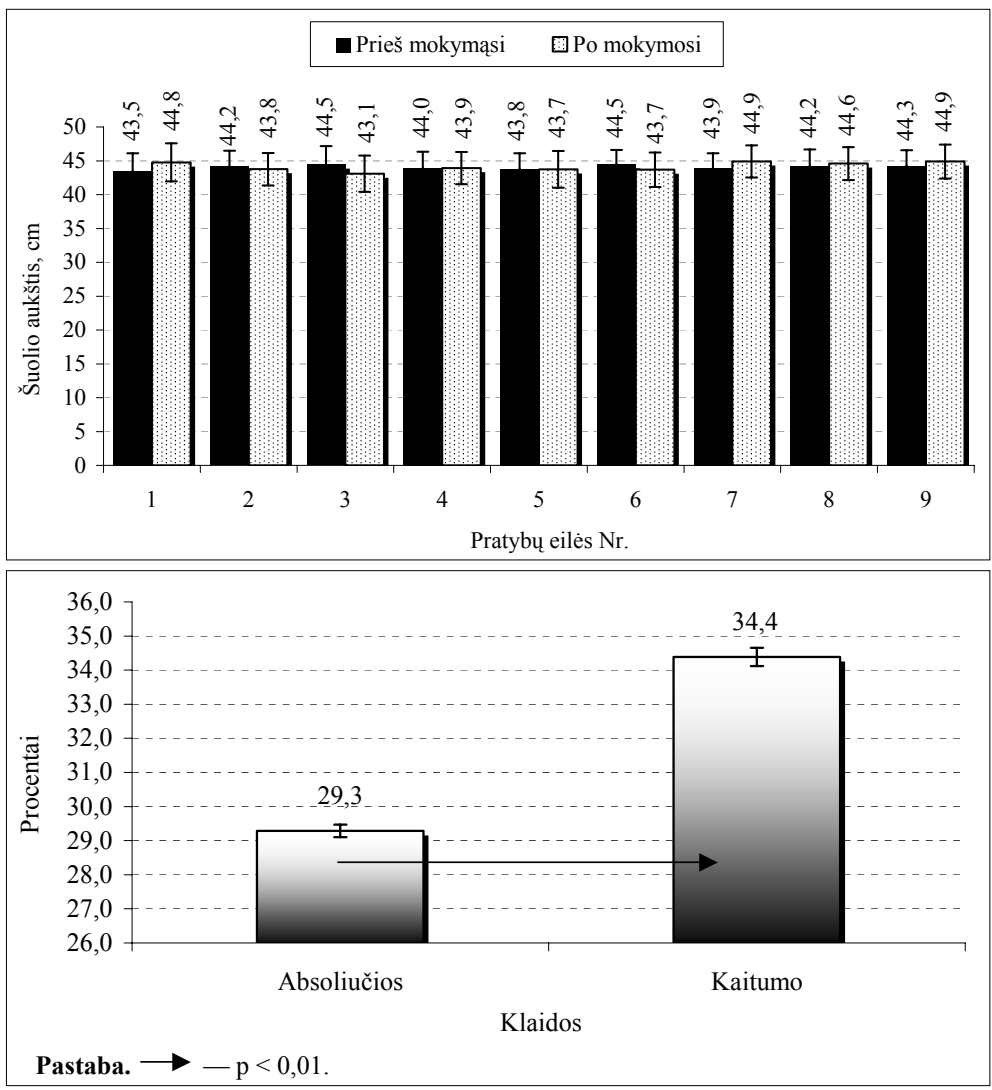

Palyginus 100 30\% MAŠ absoliučias ir kaitumo klaidas per 9 pratybas, didžiausias skirtumas nustatytas tarp pirmų ir antrų pratybų rodiklių $(\mathrm{p}<0,05)$. Kaitumo klaidos po pirmos dienos sumažèjo $18,2 \pm 6,5 \%(\mathrm{p}<0,05)$, absoliučios $13,2 \pm 10,1 \%(\mathrm{p}<0,05)(4 \mathrm{pav}$.$) . Kaitumo klaidos$ sumažèjo reikšmingai daugiau nei absoliučios $(\mathrm{p}<0,05)$.

Absoliučios klaidos mažèjo priklausomai nuo mokymosi dienos $(\mathrm{p}<0,001)$. Palyginus pirmu $(1,2 \pm 0,4 \mathrm{~cm})$ ir paskutinių $(0,9 \pm 0,2 \mathrm{~cm})$ pratybu absoliučias klaidas, aptiktas statistiškai patikimas skirtumas $(\mathrm{p}<0,05)$. Devintą dieną tiriamiesiems atliekant $30 \%$ MAŠ, nustatytas mažiausios absoliučių klaidų reikšmès. Pirmos pratybos labiausiai paveikè šuolio aukščio tikslumą (5 pav.).

Kaitumo klaidos taip pat mažèjo priklausomai nuo mokymosi dienos $(\mathrm{p}<0,001)$. Palyginus pirmų pratybų 100 šuolių kaitumo klaidas su kitų pratybų rodikliais, nustatytas statistiškai patikimas skirtumas $(\mathrm{p}<0,01)$. Jau antrų pratybu metu tiriamieji šuolius atliko darydami statistiškai patikimai mažiau kaitumo klaidų nei pirmą dieną $(\mathrm{p}<0,01)$. Mažiausios kaitumo klaidos nustatytos 9-ų pratybų metu $(1,0 \pm 0,3 \mathrm{~cm})$, didžiausios 1 -u $(1,6 \pm 0,9 \mathrm{~cm})(6$ pav. $)$.

Suskirsčius atliktus šuolius i 10 serijų (viena serija - 10 šuoliu) matyti, kad pirmose pratybose absoliučios $(24,5 \pm 15,6 \%)$ ir kaitumo
2 pav. Maksimalaus aukščio šuolio rodiklių kaita per 9 pratybas prieš šuolių mokymąsi ir po jo
3 pav. $10030 \%$ maksimalaus aukščio šuolių absoliučių ir kaitumo klaidų vidutinès reikšmès per 9 pratybas 
4 pav. $10030 \%$ maksimalaus aukščio šuolių absoliučių ir kaitumo klaidų skirtumo reikšmès per 9 pratybas
5 pav. $10030 \%$ maksimalaus aukščio šuolių absoliučių klaidų reikšmès per 9 pratybas
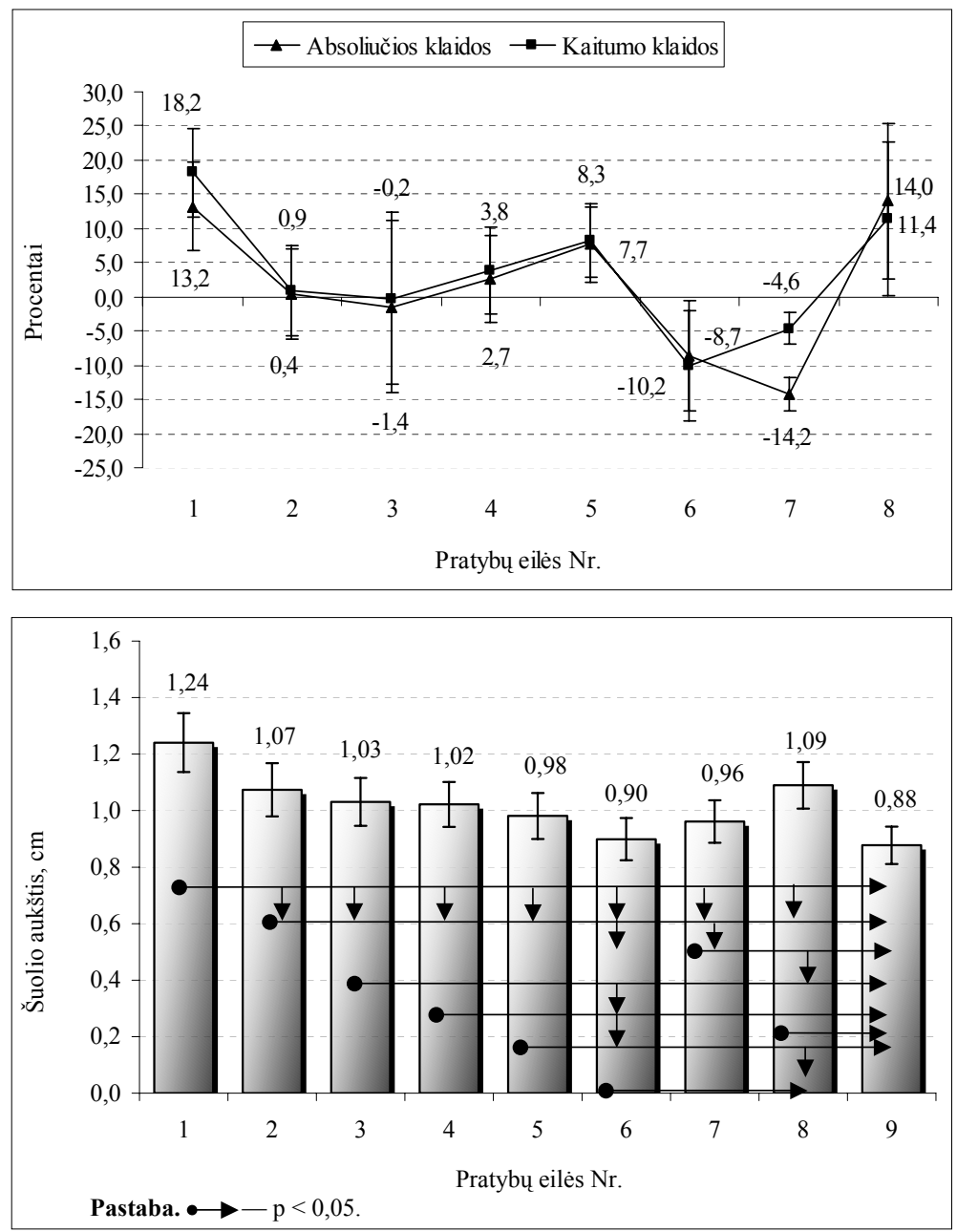

6 pav. $10030 \%$ maksimalaus aukščio šuolių kaitumo klaidų reikšmès per 9 pratybas

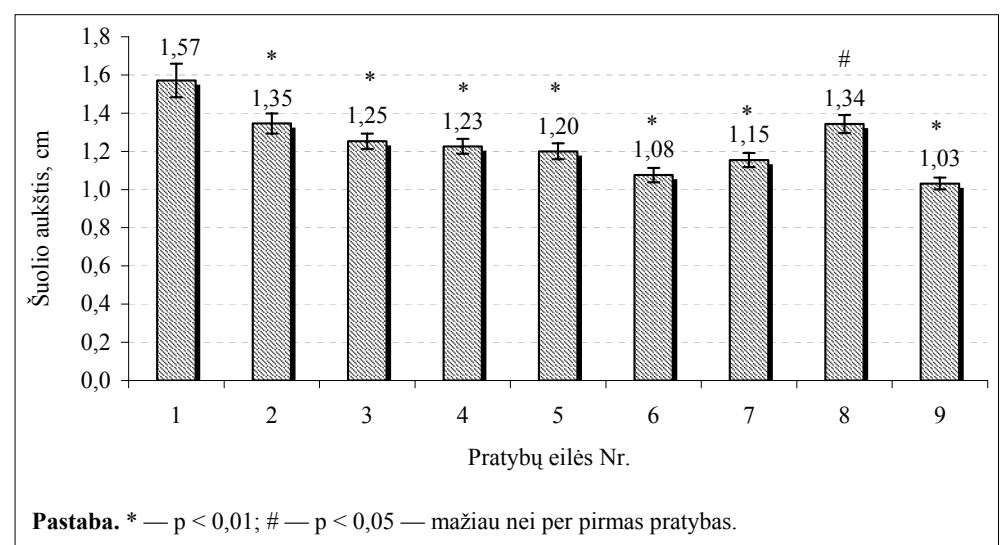

$(42,3 \pm 10,3 \%)$ klaidos labiausiai sumažèjo po pirmų 10 šuoliu $(\mathrm{p}<0,05)$. Pirmose pratybose tiriamieji antrus 10 šuolių $(1,0 \pm 0,1 \mathrm{~cm})$ jau atliko tiksliau nei pirmus $10(2,0 \pm 0,3 \mathrm{~cm})$ $(\mathrm{p}<0,05)$. Kaitumo klaidos pirmose pratybose taip pat labiausiai sumažèjo po pirmu 10 šuoliu (nuo 2,5 $\pm 0,2$ iki $1,1 \pm 0,1 \mathrm{~cm} ; \mathrm{p}<0,05$ ). Visose kitose pratybose statistiškai patikimo skirtumo tarp šuolių serijų rodiklių neaptikta $(p>0,05)$ (7 pav.). Atliktų pratybų skaičiaus ir šuolių serijų absoliučių klaidų ryšys buvo statistiškai reikš- mingas $(p<0,05)$, kaitumo - nereikšmingas $(\mathrm{p}>0,05)$.

Palyginus pirmų ir paskutinių pratybų rodiklius matyti, kad tikslių šuoliu (atliktų $<1 \mathrm{~cm}$ nuokrypiu) statistiškai patikimai padaugèjo $(\mathrm{p}<0,05)$, netikslių (atliktų $>3 \mathrm{~cm}$ nuokrypiu) - sumažèjo $(\mathrm{p}<0,01)$. Šuoliu, kurie buvo atlikti $1-3 \mathrm{~cm}$ nuokrypiu, skaičius statistiškai patikimai nekito 3 savaičių šuolių mokymosi laikotarpiu $(p>0,05)$ (8 pav.). Taigi, tiriamiesiems atlikus $10030 \%$ MAŠ, šuolių tikslumas pagerèjo. 

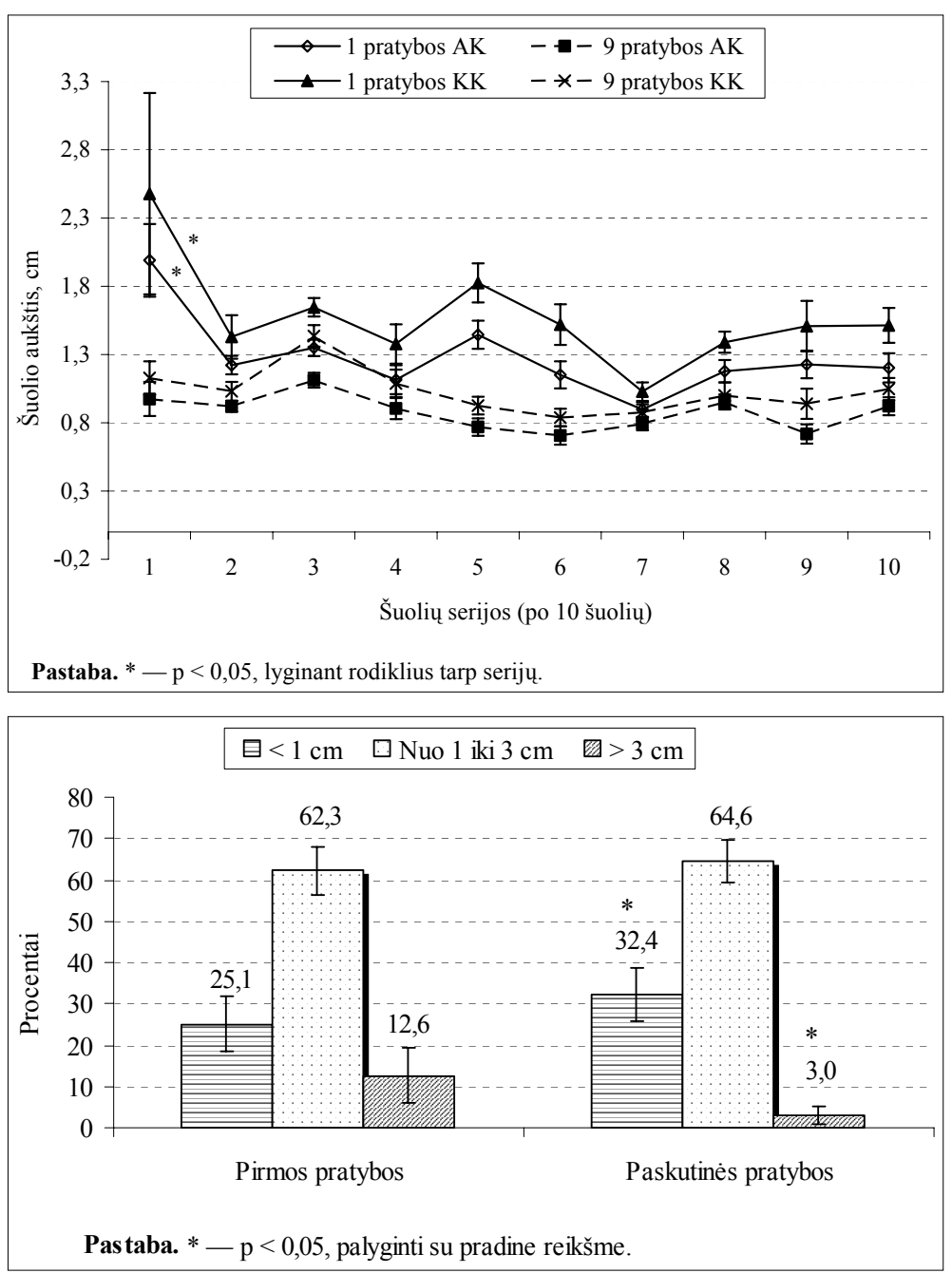

7 pav. $10030 \%$ MAŠ pirmų ir paskutinių pratybų absoliučiu (AK) ir kaitumo klaidụ (KK) reikšmės 10 serijų atžvilgiu (serija - po 10 šuolių)
8 pav. $10030 \%$ maksimalaus aukščio šuolių pirmų ir paskutinių pratybų absoliučių klaidų palyginimas

\section{REZULTATŲ APTARIMAS}

Tyrimo rezultatai parode, kad: a) per 9 pratybas reikšmingai pagerejo šuolių stabilumas ir tikslumas; b) šuoliu stabilumas pagerèjo reikšmingiau nei tikslumas; c) didžiausi pokyčiai pastebimi per pirmų pratybų pirmus 10 šuolių.

Ar atliekant daugkartinius 30\% maksimalaus šuolio aukščio šuolius pasireiškia raumenų nuovargis? J. D. Lawther (1977) atlikti tyrimai parode, kad nedidelio raumenų nuovargio metu judesio atlikimo tikslumas pablogejja, bet mokymosi efektyvumas nepakinta. Tačiau didelis raumenų nuovargis judesių mokymąsi padaro mažiau efektyvų. Po kiekvienos dienos šuolių mokymosi pratybų matavome maksimalų šuolio aukšti, kuri palyginome su tos pačios dienos prieš mokymąsi išmatuotu. Šuolio aukštis po mokymosi galejo sumažèti dèl atsirandančio nuovargio, tačiau gauti rezultatai parodè, kad maksimalių pastangų šuolio aukštis prieš $10030 \%$ MAŠ ir po jų nesiskyrè (2 pav.). Tai rodo, kad atliekant 100 30\% MAS̆ di- delis nuovargis, kuris galètų sumažinti mokymosi efektyvuma, nepasireškia.

Ar per 9 pratybas pagerèja $30 \%$ MAŠ tikslumas ir stabilumas? Tiriamieji, mokydamiesi atlikti tikslius šuolius, buvo informuojami apie atlikto šuolio aukštį. Grį̌tamosios informacijos suteikimas lèmé spartesnį šuolių mokymąsi (Mickevičienè ir kt., 2006).

D. M. Wolpert ir kt. (2001) nurodo, kad pagrindinis judesiu mokymosi tikslas yra pagerinti judesio atlikimo stabilumą. Rodiklių kaitumas rodo sensomotorinès sistemos nestabilumą (Newell, Corcos, 1993; Beers et al., 2004). Taigi kuo mažesnis judesio kaitumas, tuo judesys stabilesnis. Tyrimo metu šuolių nestabilumą rodè kaitumo klaidos, kurios po mokymosi patikimai sumažejo (3 pav.). Jau per antras pratybas tiriamiesiems atliekant šuolius nustatytos statistiškai patikimai mažesnès kaitumo klaidų reikšmès nei pirmą dieną. Mažiausios kaitumo klaidų reikšmès nustatytos per paskutines, didžiausias - per pirmas pratybas (6 pav.). Kai kurie autoriai (Beers 
et al., 2004) pabrèžia, kad net išmoktas judesys atliekamas šiek tiek skirtingai, tad tikètis kaitumo išnykimo nereikia.

Išmokimą tiksliau atlikti šuolius parodè netikslių šuolių (atliktų $>3 \mathrm{~cm}$ nuokrypiu) skaičiaus ryškus sumažejjimas ir tikslių (atliktų $<1 \mathrm{~cm}$ nuokrypiu) padaugèjimas (8 pav.). Šuolių atlikimo tikslumą taip pat parodè ir absoliučių klaidų sumažèjimas (5 pav.). Taigi galima teigti, kad po 9 šuolių mokymosi pratybu pagerèjo šuolių tikslumas ir stabilumas, t. y. tiriamieji išmoko tiksliau atlikti 30\% MAŠ. Daugkartinis šuoliu atlikimas lèmė šuolių kaitumo klaidų mažèjimą.

Ar šuolių mokymosi metu susidarè nauji vidiniai modeliai? Kai motorinè sistema prisitaiko prie naujos dinamiškos aplinkos, galvos smegenu motorinèje žievèje susikuria vidiniai modeliai, kurių dèka centrinè nervų sistema valdo jutima, leidžianti atlikti judesi kuo tiksliau (Shadmehr, Mussa-Ivaldi, 1994; Imamizu et al., 2000; Takahashi et al., 2006). Atlikto tyrimo metu ne tik po pirmu, bet ir po dešimties mokymosi pratybu tiriamieji tiksliau atliko šuolius (7 pav.). Taigi mokymosi metu pirmi 10 šuolių daugiausia lemia mokymosi eigą. Jų metu tiriamieji išmoksta „,dozuoti“ kojų raumenų jègą, noredami tiksliai atliktų $30 \%$ MAS̆. Tyrimo rezultatai iš dalies prieštarauja kitų autorių (Okano et al., 2000; Korman et al., 2003) teiginiui - norint kad judesys būtų atliktas kuo tiksliau, reikia nemažai laiko. Gana tikslius šuolius mūsų tiriamieji atliko jau po 10 kartojimų. Taigi galima teigti, kad stengiantis atlikti kuo tikslesnius šuolius prisitaikoma prie naujos dinamiškos aplinkos, ir tai lemia naujų vidiniu modelių susidarymą.

\section{IŠVADOS}

Šuolių stabilumas ir tikslumas atliekant pirmus 10 šuoliu padidejja panašiai kaip ir toliau atliekant 890 šuolių. Tikètina, kad per labai trumpą laikotarpi (atliekant 10 šuolių) galvos smegenyse susidaro vidiniai modeliai, leidžiantys kur kas stabiliau ir tiksliau atlikti gana paprastą judesi $30 \%$ maksimalaus aukščio šuoli iš vietos.

\section{LITERATŪRA}

Bays, P. M., Wolpert, D. M. (2006). Action and consequences in bimanual interaction are represented in different coordinate systems. Journal of Neuroscience, 26 (26), $7121-7126$.

Beers, R. J., Haggard, P., Wolpert, D. M. (2004). The role of execution noise in movement variability. Journal of Neurophysiology, 91, 1050-1063.

Cothros, N., Wong, J. D., Gribble, P. L. (2006). Are there distinct neural representations of object and limb dynamics? Experimental Brain Research, 173, 689-697.

Imamizu, H., Miyauchi, S., Tamada, T. et al. (2000). Human cerebellar activity reflecting an acquired internal model of a new tool. Nature, Vol. 403, 192-195.

Jeannerod, M. (1994). The timing of natural apprehension. Journal of Motor Behavior, 16, 201-211.

Korman, M., Raz, N., Flash, T., Karni, A. (2003). Multiple shifts in the representation of a motor sequence during the acquisition of skilled performance. PNAS: Neuroscience, Vol. 100, 21, 12492-12497.

Lawther, J. D. (1977). The Learning and Performance of Physical Skills. Second Edition. Prentice-Hall Inc.: Englewood Cliffs, N. J.

Lee, T. D., Genovese, E. D. (1989). Distribution of practice in motor skill acquisition: Different effects of discrete and continuous tasks. Research Quarterly for Exercise and Sport, 60, 59-65.

Magill, R. A., Hall, K. G. (1990). A review of the contextual interference effect in motor skill acquisition. Human Movement Science, 9, 241-289.

Magill, R. A. (2006). Motor Learning and Control: Con- cepts and Applications. McGraw-Hill International edition.

Mattar, A. A., Gribble, P. L. (2005). Motor learning by observing. Neuron, 46, 153-160.

McCullagh, P., Weiss, M. R., Ross, D. (1989). Modeling considerations in motor skill acquisition and performance: An integrated aproach. In K. Pandolf (Ed.), Exercise and Sport Science Reviews (Vol. 17, pp. 475-513). Baltimore: Williams and Wadkins.

Mickevičienè, D., Skurvydas, A., Drebulys, G. ir kt. (2006). Grižžtamosios informacijos ir judesio kaitumo ryšys atliekant šuolius i aukšti iš vietos $50 \%$ maksimaliosios jègos intensyvumu. Ugdymas. Kūno kultūra. Sportas, 2 (61), 25-31.

Newell, K. M., Corros, M. C. (1993). Variability and Motor Control. Human Kinetics. P. 499.

Okano, H., Hirano, T., Balaban, E. (2000). Learning and memory. PNAS, Vol. 97, 23, 12403-12404.

Salmoni, A. W., Schmidt, R. A, Walter, C. B. (1984). Knowledge of results and motor learning: A review and critical appraisal. Psychological Bulletin, 95, 355-386.

Schmidt, R. A. (1991). Frequent augmented can degrade learning: Evidence and interpretations. In J. Requin and G. E. Stelmach (Eds.), Tutorials in Motor Neuroscience (pp. 59-75). Dordrecht, The Netherlands: Kluwer.

Schmidt, R. A., Lee, T. D. (1999). Motor Control and Learning: A Behavioral Emphasis. Human Kinetics.

Shadmehr, R., Mussa-Ivaldi, F. A. (1994). Adaptive representation of dynamics during learning of a motor task. Journal of Neuroscience, Vol. 14, 5, 3208-3224. 
Shadmehr, R., Wise, S. P. (2005). The Computational Neurobiology of Reaching and Pointing: A Foundation for Motor Learning. MIT Press xviii +575 pp.

Shapiro, D. C., Schmidt, R. A. (1982). The schema theory: Recent evidence and development implications. In J. A. S. Kelso and J. E. Clark (Eds.), The Development of Movement Control and Co-ordination (pp. 113-150). New York: Wiley.

Takahashi, C. D., Nemet, D., Rose-Gottron, C. M. et al. (2006). Effect of muscle fatigue on internal model forma- tion and retention during reaching with the arm. Journal of Applied Physiology, 100, 695-706.

Wolpert, D. M., Ghahramani, Z., Flangan, J. R. (2001) Perspectives and problems in motor learning. TRENDS in Cognitive Sciences, Vol. 5, 11, 487-494.

Wulf, G., Shea, C. H. (2002). Principles derived from the study of simple skills do not generalize to complex skill learning. Psychonomic Bulletin \& Review, 9 (2), $185-211$.

\title{
DYNAMICS OF JUMP PERFORMANCE ACCURACY AND STABILITY IN LEARNING PROCESS
}

\author{
Edita Lingytė, Albertas Skurvydas, Jūratė Kudirkaitė, Kazimieras Pukẻnas, Tomas Venckūnas, \\ Viktoras Šilinskas, Raminta Sakalauskaitė \\ Lithuanian Academy of Physical Education, Kaunas, Lithuania
}

\begin{abstract}
The aim of the study was to examine the motor learning process of jumping accuracy and stability ( $30 \%$ of maximal jump height) performance.

Eight non-athletic males (19-21 years of age, $182.0 \pm 3.5 \mathrm{~cm}$ height, $77.5 \pm 9.1 \mathrm{~kg}$ body mass) learned for 3 weeks ( 3 times a week) to perform accurate counter-movement vertical jumps ( $30 \%$ height of maximum jump) on a Kistler tensoplate. Four days before the learning program, the subjects were given instructions how to perform jumping, and they were allowed to familiarize with the procedure and to try maximal jumps. While jumping, the subjects kept their arms akimbo, trunk as straight as possible, bent knees to 90 degrees before the beginning of the propulsion phase, and landing with straight legs. Before each training session, after a proper warm-up, the subjects performed 3 maximum effort jumps ( $20 \mathrm{~s}$ of rest in between them) to estimate $30 \%$ maximal jump height value. Then 100 accurate (30\% of maximal jump height) jumps were made with 5 seconds of rest in between. After each jump, the subjects were given verbal feedback of the height of the jump. In $3 \mathrm{~min}$ of the last (100 th) accuracy jump, the subjects repeated 3 maximum effort jumps.

There were no statistically significant differences in maximal jump height before and after each learning session ( $p>0.05)$. Both absolute and variable errors were significantly decreased after the learning program $(\mathrm{p}<0.05)$. Jump accuracy was significantly increased at the last training session compared to the first day of training. The first 10 jumps of the first workout were performed least accurately and with most variability.

In conclusion, motor learning increases accuracy and decreases variability of jumps performed at $30 \%$ of maximal jump height. Internal model is most likely to be acquired during the first 10 jumps.
\end{abstract}

Keywords: motor learning, vertical jumps, internal models.

Gauta 2006 m. gruodžio $6 \mathrm{~d}$.

Received on December 6, 2006

Edita Lingytė

Lietuvos kūno kultūros akademija

(Lithuanian Academy of Physical Education)

Sporto g. 6, LT-44221 Kaunas

Lietuva (Lithuania)

Tel +37037302674

E-mail 1edita3@yahoo.com 